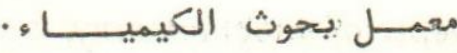

معهد بحوث صجة الحيوان ـ الدقي ـ الجيزة.

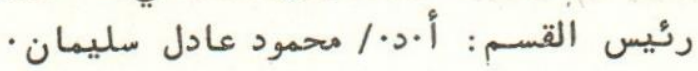

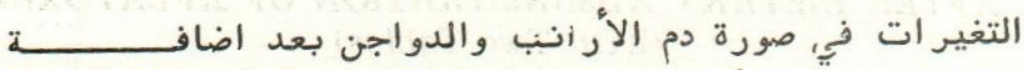

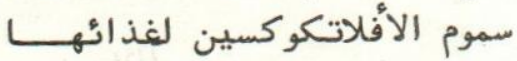

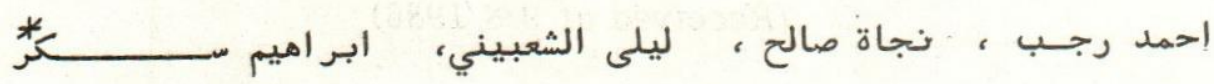

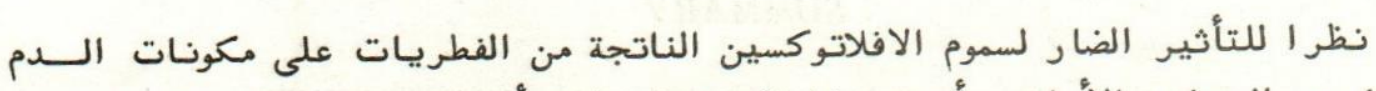

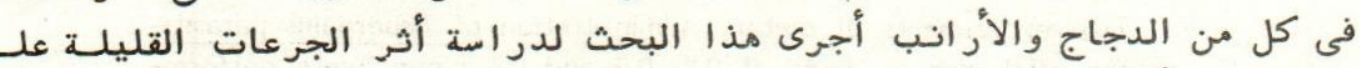

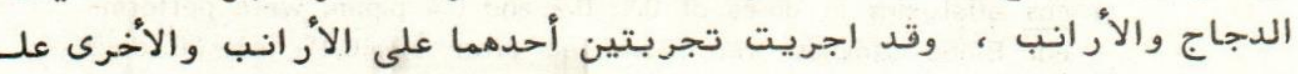

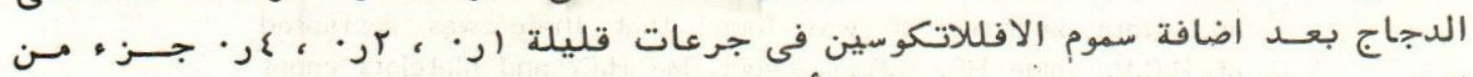

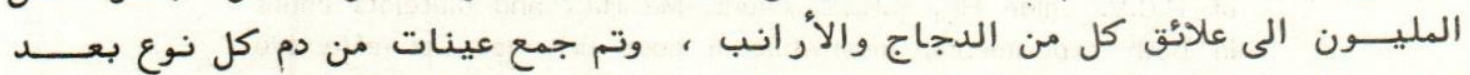

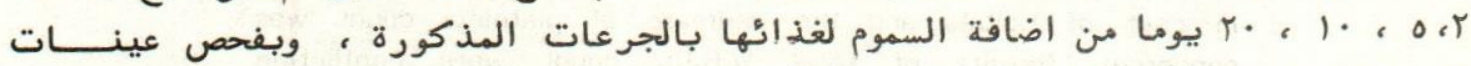

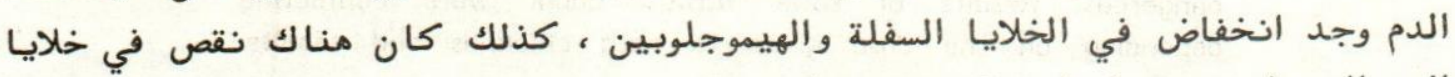

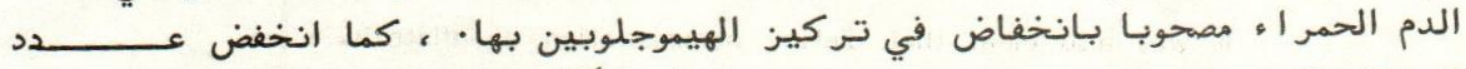

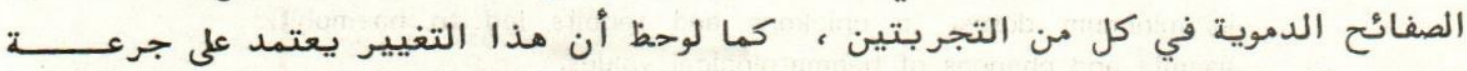

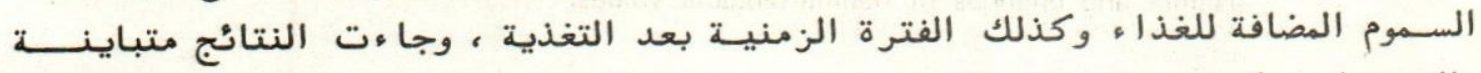

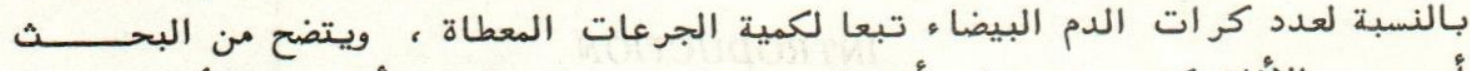

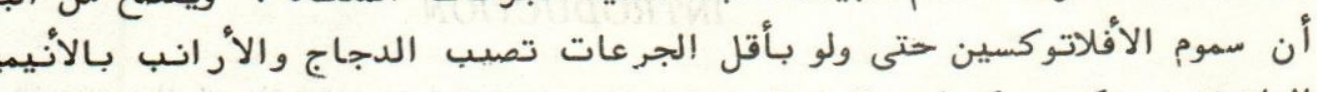

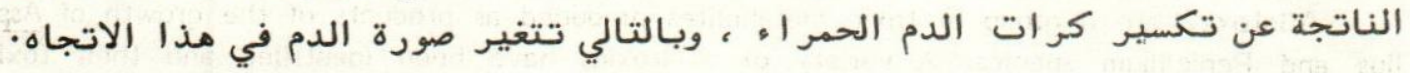




\title{
HAEMATOLOGICAL PARAMETERS IN CHICKENS AND RABBITS AFTER DIETARY ADMINISTRATION OF AFLATOXIN \\ (With Two Tables)
}

\author{
By \\ A.M. RAGAB; N.A. SALEH; L.M. ELSHABINY and I.H. SOKKAR \\ (Received at 9/8/1986)
}

\begin{abstract}
SUMMARY
Two experiments of dietary administration of Aspergillus parasiticus aflatoxins in doses of $0.1,0.2$ and 0.4 p.p.m. were perform-

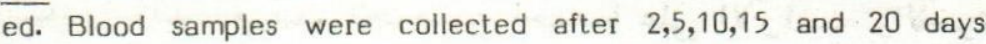
and were analysed. It was found that there was decreased of P.C.V. value HB, R.B.Cs. count, M.C.H.C. and platelets count in both experiments, meanwhile a dose 0.1 was not effective in case of rabbits and the decrease of platelets count was dangerous. Results of total W.B.Cs. count were conflicting depending on the dose given to both chicknes and rabbits. It was also clear that dietary administration of aflatoxin, even in minimum doses, to chickens and rabbits led to haemolytic anemia and changes of haematological values.
\end{abstract}

\section{INTRODUCTION}

Aflatoxins are a group of toxic metabolites produced as products of the growth of Aspergillus and Penicillium species. A variety of aflatoxins have been identified and their toxicities were defined (GOLDBLATT, 1969). The aflatoxins are highly carcinogenic to some species (WOGEN and NEWBERNE, 1967), meanwhile they are acutely toxic to other species such as chickens (SMITH and HAMILTON, 1970). The response of the haemopiotic system during aflatoxicosis has not been studied extensively even prior to the discovery of aflatoxins. Aspergillus flavus was reported to cause haemorrhagic anaemia syndrome. The toxins have not been investigated directly, but TUNG, et al. (1970 \& 1971) found that dietary aflatoxins caused decreased capillary fragility in young chicknes.

The specific effects of aflatoxins on circulating blood cells are investigated only superficially even in our environment (SALEH, 1984 and ABD-ELKALECK, 1985).

So the objective of the present study is to investigate the status of circulating blood cells during the long term dietary administration of minimum doses of aflatoxins in chickens and rabbits.

\section{MATERIAL and METHODS}

Thirty-six apparently healthy broders 60-days old previously vaccinated according to the program of the Poultry General Company (P.G.C) were kept hygienically and fed on basal ration

Assiut Vet.Med.J. Vol. 18, No. 35, 1987. 
A.M. RAGAB, et al.

provided from P.G.C. The basal ration contained no detectable level of aflatoxins on analysis. These birds were divided into 4 groups, each of 9 birds, the fourth group was considered as a control group which was kept on basal ration only. To the first three groups aflatoxin was added at the level of $0.1,0.2$ and 0.4 p.p.m. respectively. The second experiment was conducted on 28 Balady rabbits, 1.8 to $2.2 \mathrm{~kg}$. each, which were kept hygienically and fed on prepared basal ration consist of corn $40 \%$ bran $35 \%$ cotton seed cake $25 \%$ and salts add $0.5 \%$, that basal ration contained no detectable amount of aflatoxins. The rabbits were divided into 4 groups each of 7 , one group was served as a control group and the other three groups received dietary aflatoxin at the same level as in the first experiment. In both experiments, aflatoxin was supplied daily for 20 days.

In the present work, aflatoxins were produced from Aspergillus parasiticus according to the method of DAVIS, et al. (1966). This fungus was kindly offered from the National Research Center. The analytical procedures described by MARTH (1967) were used for quantitative measurement of aflatoxin by thin layer chromatography against standard B aflatoxin 5/ug/ml. After separation of known amount of aflatoxin, the diet was inoculated with the previously mentioned doses.

Blood samples were taken from the wing vein in chickens and ear vein of rabbits pre-experiment and after 2,5,10,15 and 20 days for blood analysis using EDTA as an anticoagulant. Obtained samples were analysed for packed cell volume, haemoglobin content, erythrocytic and leucocytic count, in addition MCHC,MCV and $\mathrm{MCH}$ were calculated. Micro-haematocrit tube method was used for determination of P.C.V. Haemoglobin was determined by the method of SUNDERMAN, et al. (1953). The total R.B.Cs. and W.B.Cs. count were made according to NATT and HERRICK $(1952)$ in chickens, while in rabbits according to SCHALM, et al. (1975). The direct method of RAGAN (1972) was used for the counting of thrombocytes.

Statistical analysis was performed comparing the values before and after feeding dietary aflatoxin using "t" test according to STELL and TORRIE (1960).

\section{RESULTS}

The results of dietary aflatoxin administered in 3 doses ( $0.1,0.2$ and 0.4 p.p.m.) to chickens and rabbits and clinical blood values (mean \pm SEM) were statistically analysed and presented in Tables (1 \& 2) which show that the effect of aflatoxin on blood parameters depended on the dose given and the duration of administration.

At the dose 0.1 p.p.m. the depression in P.C.V. value of chickens was noticed after the 20th day of administration; (P/ 0.05) that dose had the same effect on P.C.V., Hb and R.B.Cs count of rabbits. At the dose 0.2 p.p.m. chickens showed a decrease in P.C.V. values which was significant after 10 days of administration ( $P / 0.05$ ), at the next observation (15 days) was $(P / 0.01)$ and at the last observation the decrease was significant (P/ 0.001). Dietary administration of aflatoxin to chickens in doses of 0.4 p.p.m. showed a depression in P.C.V. level which was significant on the 5 th day of observation $(P / 0.05)$ and at 10,15 and 20 days of the experiment was also significant (P/ 0.001). The same observation was noticed in $\mathrm{Hb}$ and R.B.Cs count. The significant decrease of R.B.Cs count was observed in the second experiment on rabbits after 5 days of administration of both 0.2 and 0.4 p.p.m. and at the same dose the significant decrease of $\mathrm{Hb}$ was observed after 2nd day of administration.

Assiut Vet.Med.J. Vol. 18, No. 35, 1987. 


\section{HAEMATOLOGICAL PARAMETERS AFTER DIETARY AFLATOXIN.}

The mean corpuscular haemoglobin concentration of chickens was decreased on the other hand the mean corpuscular volume and mean corpuscular haemoglobin was increased depending on the dose and duration of administration. The effect of administration of aflatoxin on the Wintrobe erythrocyte indices in the rabbits were the same as in chicknes but the values were significant latter at the 15 th and 20 th day of administration.

Dietary administration of aflatoxin for 20 days dangerously affected the platelets count of rabbits from the 5 th day at dose 0.4 p.p.m. ( $P / 0.01)^{\circ}$ and later observation was $(P / 0.001)$ however at dose of 0.2 p.p.m. the counting of thrombocytes of rabbits was decreased significantly $(P / 0.05)$ at the 10 th day. At 15 and 20 days observations were significant at $(P / 0.001)$. The decline of platelets count which was observed at dose 0.1 p.p.m. was not significant allover the period of observation and appeared to be significant at 20th day after administration of aflatoxin. In chickens the thrombocytes were decreased allover the period of observation but appear to be significantly affected at the dose of 0.2 and 0.4 p.p.m. at 15th and 20th days of administration (P/ 0.05).

The results of W.B.Cs counts were conflecting in both chickens and rabbits at dose of 0.1 p.p.m., the count was increased without being statistically significant. In both doses 0.2 and 0.4 p.p.m. the changes were increased at the begining then decreased.

\section{DISCUSSION}

The presented data clarified that the aflatoxin even in very low doses affected the blood parameters (P.C.V., $\mathrm{Hb}$ and R.B.Cs. count). This adverse effect of aflatoxin on avian blood constituents had been also reported in turkeys (WANNOP, 1961), ducklings and New Hampshire chicks (BROWN and ABRAMS, 1965 and TUNG, et al. 1975). They observed decrease in P.C.V., R.B.Cs. and $\mathrm{Hb}$ which agreed with the changes reported here.

The increase in M.C.V. and the decrease of M.C.H.C. in the present work indicated that the type of anemia was haemolytic type (SILVER, 1970). However TUNG, et al. (1975) suggested that aflatoxin associated anemia was haemolytic without giving the direct picture of the type of anemia. TUNG, et al. (1975) suggestion was based on decreased bone marrow lipid and increased splenic weight and volume.

A possible explanation of haemolytic anemia in our study was coupled with a hyperactivity of bone marrow (TUNG, et al. 1975) leading to production of red blood cells with impaired integrity which were easily destructed in the circulation, that opinion agree with those of $A B D$ EL KHALECK (1985).

The picture of white blood cells in the present work can be classified according to the dose and duration of administration into two phases. In the first phase the count was increased in all the experimental period of the dose $0.1 \mathrm{ppm}$ and also to the 5 th day after administration of higher doses 0.2 and 0.4 p.p.m. In that phase the bone marrow of both chickens and rabbits was highly active that is generally related to haemolytic anemia (SILVER, 1970). The next phase in the present study was characterised by decrease of W.B.Cs. count. That picture of moderate leukocytosis followed by leukopenia was recorded in many cases of chemical toxicity which cause haemolytic anemia as stated by DEKNUDT, et al. (1977) in lead toxicity. The two phases of leukocytes were found also in many cases of acquired haemolytic anemia as described by SONNEWIRTH and JARATT (1980). 
A.M. RAGAB, et al.

There is no recorded data about the effect of dietary administration of aflatoxin on the blood platelets. The reduction in number of circulating platelets to below the minimum control number after administration of aflatoxin in both rabbits and chickens in the present study was expected with the old theory of haemorrhagic effect of aflatoxin (FORGACS and CARLL, 1962 and BROWN and ABRAMS, 1965) but the thrombocytopenia after the new theory of TUNG, et al. (1975) was not expected although HAMILTON and HARRIS (1971) and TUNG, et al. (1975) found hypersplenism which may be resulted in thrombocytopenia as the enlarged organ places greater demands for its share of available platelets (PENNY, et al. 1966). The decrease in blood platelets was also metwith. in many of the chemical toxicities as penicillin, streptomycin and chlorpromazine (SCHALM, et al. 1975) estrogen (STEINBERGA, 1964) and many of plant poisoning as Brackenfren (SIPPEL, 1952 and PRITCHARD, et al. 1956).

\section{REFERENCES}

Abd El-Khaleck, M.M. (1985): Some toxicological and clinical studies on Aspergillus toxins in poultry with special reference to its effect on some body mineral levels. M.V.Sc., Fac. of Vet. Med., Zagazig Univ.

Brown, J.M.M. and Abrams, L. (1965): Biochemical studies on aflatoxicosis, Ondersteport J. Vet. Res., 32, 119-146. Davis, N.D.; Diener, U.L. and Eldridge, D.W. (1966): Production of aflatoxin B and G, by Aspergi-
llus flavus in semisynthetic medium, Applied Microbiology, 14, 378-380.

Deknudt, G.; Colle, A. and Gerber, G.B. (1977): Mutation Res., 45, 77-82. Cited in lead Toxicity, 1st Ed. by Singwol, R.L. and Thomas, J.A. (1980). Urabn and Schwarzenberg. Baltimore and Munich.

Forgacs, J. and Carll, W.L. (1962): Mycotoxicosis. Advan. Vet. Sci., 7, 273-282.

Goldblatt, L.A. (1969): Aflatoxin. 1st Ed. Academic Press Inc.

Hamilton, P.B. and Harris, J.R. (1971): Interactions of aflatoxin with Candida albicans infections and other stresses in chicken, Poultry Sci., 50., 906-912.

Marth, E.H. (1967): Methods for the qualitative and quantitative determination of aflatoxins. J. Milk Food Technol., 30, 317-320.

Natt, M.P. and Herrick, C.A. (1952): A new blood diluent for counting erythrocytes and leucocytes of the chicken. Poultry Sci., 31, 375-738.

Penny, R.; Rozenberg, M.C. and Firkin, B.G. (1966): The splenic pool. Blood, 27, 1-8.

Pritchard, W.R.; Rehfeld, C.E.; Mizuno, N.S.; Sautter, J.H. and Schultze, M.O. (1956): Studies on Trichloroethylen extracted foods, I: Experimental production of acute aplastic anemia in young heifers. Amer. J. Vet. Res., 17, 425-434.

Ragan, H.A. (1972): Platelets agglutination induced ethylene diaminotetraacetic acid in blood samples from a miniature pigs. Amer. J. Vet. Res., 33, 2601-2608.

Saleh, N.A. (1984): Studies on fungus isolated from some food components, Ph.D. Thesis, Fac. of Vet. Med. Assiut Univ.

Schalm, O.W.; Jain, N.C. and Corroll, E.J. (1975): Veterinary Haematology, 3rd Ed. Lea Febiger, Philadelphia.

Silver, R.T. (1970): Morphology of the blood and marrow in clinical practice. Grune and Stratton Inc., New York.

Smith, J.W. and Hamilton, P.B. (1970): Aflatoxicosis in the broiler chicken. Poultry Sci., 49, 207-215.

Assiut Vet.Med.J. Vol. 18, No. 35, 1987. 


\section{HAEMATOLOGICAL PARAMETERS AFTER DIETARY AFLATOXIN}

Sippel, W.L. (1952): Bracken fren poisoning. J. Amer. Vet. Med. Ass., 121, 9-12.

Sonnewirth, L.C. and Jaratt, L. (1980): Gradwohl's Clinical Laboratory Methods and Diagnosis. 8th Ed. The C.V. Mosby Company.

Steinberg, S. (1964): Aplastic anemia in a dog. J. Amer, Vet. Med. Ass., 157, 966-972.

Stell, R.G.D. and Torrie, J.H. (1960): Principles and Procedures of Statistics, MC Graw Hill, New York.

Sunderman, F.W.; MacFate, R.P.; McFayden, D.A.; Stevenson, G.F. and Copeland, B.C. (1953): Symposium on clinical hemoglobinometry. Amer. J. Clin. Path., 23, 519-598.

Tung, H.T.; Donaldson, W.E. and Hamilton, P.B. (1910): Effects of aflatoxin on some marker enzymes of lysosomes. Biochem. Biophys. Acta, 222, 665-667.

Tung, H.T.; Smith, J.W. and Hamilton, P.B. (1971): Aflatoxicosis and bruising in the chicken. Poultry Sci., 50, 795-800.

Tung, H.T.; Cook, F.W.; Wyatt, R.D. and Hamilton, P.B. (1975): The anemia caused by aflatoxin. Poultry Sci., 54, 1962-1969.

Wannop, C.C. (1961): The histopathology of Turkey "X" disease in Great Britain. Avian Dis., 5, 371-381.

Wogan, G.N. and Newberne, L. (1967): Dose response characteristics of aflatoxin $B_{1}$ carcinogenesis in the rat. Cancer Res., 27, 2370-2376. 
A.M. RAGAB, et al.

Table (1)

Haematological changes in chickens given dietary aflatoxin in different doses $(0.1,0.2$ and $0.4 \mathrm{ppm})$

\begin{tabular}{|c|c|c|c|c|c|c|c|}
\hline \multicolumn{2}{|c|}{$\begin{array}{c}\text { Diatary doses of } \\
\text { aflatoxin ppm \& } \\
\text { haematological items }\end{array}$} & $\begin{array}{l}\text { before feeding } \\
\text { dietary } \\
\text { aflatoxin }\end{array}$ & $\begin{array}{l}\frac{2 \text { nd day }}{\text { after }} \\
\text { feeding }\end{array}$ & $\begin{array}{l}\frac{5 \text { th day }}{\text { after }} \\
\text { feeding }\end{array}$ & $\begin{array}{l}10 \text { th day } \\
\text { after } \\
\text { feeding }\end{array}$ & $\begin{array}{l}15 \text { th day } \\
\text { after } \\
\text { feeding }\end{array}$ & $\begin{array}{l}20 \text { th day } \\
\text { after feeding } \\
\text { aflatoxin }\end{array}$ \\
\hline \multirow{4}{*}{$(P C V)$} & $0.1 \mathrm{ppm}$ & $38.87+0.30$ & $38.58+0.29$ & $38.76+0.90$ & $38.94+0.88$ & $36.97+0.88$ & $36.58+0.83 *$ \\
\hline & $0.2 \mathrm{ppm}$ & $37.98+0.55$ & $37.53+0.57$ & $38.17 \pm 0.32$ & $37.44+0.35 *$ & $36.57 \pm 0.37 * *$ & $35.57 \pm 0.40 * * *$ \\
\hline & $0.4 \mathrm{ppm}$ & $40.62+0.91$ & $40.91 \pm 0.96$ & $36.70+0.69 *$ & $35.77+0.59 * * *$ & $34.91 \pm 0.65 * * *$ & $34.02+0.67 * * *$ \\
\hline & Control & $39.23+0.69$ & $39.23 \pm 0.66$ & $39.22 \pm 0.65$ & $39.24+0.61$ & $39.15 \pm 0.57$ & $38.93 \pm 0.54$ \\
\hline \multirow{4}{*}{$\begin{array}{c}(\mathrm{Hb}) \\
9 \%\end{array}$} & $0.1 \mathrm{ppm}$ & $12.20+0.10$ & $12.09+0.10$ & $12.01 \pm 0.10 *$ & $11.59 \pm 0.12^{* *}$ & $11.30 \pm 0.10 * * *$ & $10.83+0.17 * * *$ \\
\hline & $0.2 \mathrm{ppm}$ & $12.43+0.17$ & $12.09+0.16$ & $11.38+0.18^{* *}$ & $11.12+0.25 * * *$ & $10.65+0.23 * * *$ & $10.18+0.21 * * *$ \\
\hline & $0.4 \mathrm{ppm}$ & $13.01+0.25$ & $12.69+0.26$ & $11.78+0.24 *$ & $11.07+0.20 * * *$ & $10.57+0.28 * * *$ & $9.87+0.26 * * *$ \\
\hline & Control & $12.69+0.29$ & $12.70 \pm 0.28$ & $12.70 \pm 0.28$ & $12.70+0.27$ & $12.68+0.26$ & $12.70 \pm 0.23$ \\
\hline \multirow{4}{*}{$\begin{array}{c}\text { (RBCs) } \\
\times 10^{2} / \mathrm{mm}^{3}\end{array}$} & $0.1 \mathrm{ppm}$ & $4.09+0.03$ & $4.02+0.05$ & $4.00 \pm 0.03$ & $3.78+0.06 * *$ & $3.67 \pm 0.04^{* * *}$ & $3.38+0.08 * * *$ \\
\hline & $0.2 \mathrm{ppm}$ & $4.05+0.08$ & $3.98+0.03$ & $3.66+0.03 * * *$ & $3.46 \pm 0.07 * * *$ & $3.23 \pm 0.07 * * *$ & $2.91+0.08^{* * *}$ \\
\hline & $0.4 \mathrm{ppm}$ & $4.23+0.08$ & $3.86 \pm 0.09 *$ & $3.21 \pm 0.08 * * *$ & $3.32+0.09 * * *$ & $3.04+0.11 * * *$ & $2.89 \pm 0.12 * * *$ \\
\hline & Control & $4.16 \pm 0.09$ & $4.17 \pm 0.09$ & $4.16 \pm 0.08$ & $4.15 \pm 0.08$ & $4.15 \pm 0.08$ & $4.15 \pm 0.08$ \\
\hline \multirow{3}{*}{$(\mathrm{MCHC})$} & $0.1 \mathrm{ppm}$ & $31.37+0.03$ & $31.36 \pm 0.05$ & $31.43+0.04$ & $30.95 \pm 0.11 * *$ & $30.90+0.11 * *$ & $30.44+0.37 * * *$ \\
\hline & $0.2 \mathrm{ppm}$ & $32.74+0.35$ & $32.22 \pm 0.25$ & $31.10 \pm 0.31 *$ & $31.11 \pm 0.31 *$ & $30.11 \pm 0.66^{* *}$ & $30.17 \pm 0.42 * * *$ \\
\hline & $0.4 \mathrm{ppm}$ & $32.06+0.29$ & $31.84 \pm 0.30$ & $30.44+0.47^{*}$ & $29.27 \pm 0.67 * *$ & $28.67 \pm 0.63 * * *$ & $27.03+0.61 * * *$ \\
\hline$\%$ & Control & $32.37 \pm 0.53$ & $32.38+0.50$ & $32.38 \pm 0.50$ & $32.35 \pm 0.45$ & $32.39 \pm 0.40$ & $32.62 \pm 0.35$ \\
\hline \multirow{4}{*}{$(M C V) u^{3}$} & $0.1 \mathrm{ppm}$ & $94.89+0.13$ & $95.87 \pm 0.73$ & $95.42 \pm 0.27$ & $99.04+1.15 * *$ & $99.59+0$. & $105.39+1.62 * * *$ \\
\hline & $0.2 \mathrm{ppm}$ & $93.76+0.87$ & $94.07 \pm 0.81$ & $99.84+0.95 * * *$ & $103.48+2.25 * * *$ & $108.07 \pm 1.95^{* * *}$ & $114.17 \pm 2.44 * * *$ \\
\hline & $0.4 \mathrm{ppm}$ & $96.04 \pm 1.01$ & $103.30 \pm 0.68 * * *$ & $120.06 \pm 2.26 * * *$ & $114.58 \pm 2.86 * * *$ & $122.45+3.82 * * *$ & $127.52+3.76 * * *$ \\
\hline & Control & $94.38 \pm 1.40$ & $94.26 \pm 1.34$ & $94.20 \pm 1.36$ & $94.48 \pm 1.23$ & $94.37 \pm 1.15$ & $93.91 \pm 1.05$ \\
\hline \multirow[b]{2}{*}{$(\mathrm{MCH})$} & $0.1 \mathrm{ppm}$ & $29.97+0.66$ & $30.04+0.32$ & $29.99+0.58$ & $30.65+0.29$ & $30.76+0.18$ & $32.06 \pm 0.36 *$ \\
\hline & $0.2 \mathrm{ppm}$ & $30.69+0.33$ & $30.32 \pm 0.33 * * *$ & $31.06+0.28$ & $32.15+0.70$ & $33.05+0.99$ & $33.09+1.24$ \\
\hline \multirow[t]{2}{*}{ uug } & $0.4 \mathrm{ppm}$ & $30.78+0.30$ & $32.89+0.38$ & $36.78 \pm 0.77 * * *$ & $33.47 \pm 0.90 * * *$ & $35.14 \pm 1.53 * * *$ & $34.55 \pm 1.48 * * *$ \\
\hline & Control & $30.49+0.18$ & $30.48+0.17$ & $30.46+0.20$ & $30.52+0.21$ & $30.53+0.22$ & $30.63+0.27$ \\
\hline \multirow{4}{*}{$\begin{array}{c}(\text { WBCs) } \\
\times 10^{3} / \mathrm{mm}^{3}\end{array}$} & $0.1 \mathrm{ppm}$ & $16.61+0.50$ & $16.71+0.48$ & $16.97+0.50$ & $17.24+0.48$ & $17.58+0.51$ & $18.09+0.63$ \\
\hline & $0.2 \mathrm{ppm}$ & $16.46 \pm 0.28$ & $16.53 \pm 0.27$ & $16.15 \pm 0.31$ & $15.77 \pm 0.28$ & $15.42 \pm 0.30$ & $14.97 \pm 0.30$ \\
\hline & $0.4 \mathrm{ppm}$ & $16.35+0.19$ & $15.80 \pm 0.22$ & $15.16 \pm 0.24 * * *$ & $14.74+0.26 * * *$ & $14.29 \pm 0.23 * * *$ & $13.75 \pm 0.26 * * *$ \\
\hline & Control & $16.59 \pm 0.44$ & $16.72 \pm 0.44$ & $16.72+0.42$ & $16.78+0.40$ & $16.84+0.39$ & $16.91 \pm 0.38$ \\
\hline \multirow{4}{*}{$\begin{array}{l}\text { Platges } \\
\times 10^{9} / 1\end{array}$} & $0.1 \mathrm{ppm}$ & $38.40 \pm 2.13$ & $38.03 \pm 2.13$ & $37.33 \pm 2.13$ & $36.71 \pm 2.04$ & $35.40+2.21$ & $33.53 \pm 1.62$ \\
\hline & $0.2 \mathrm{ppm}$ & $39.70 \pm 1.99$ & $39.15 \pm 1.99$ & $37.46 \pm 1.96$ & $36.16+1.80$ & $35.37 \pm 1.89$ & $33.62 \pm 2.08 *$ \\
\hline & $0.4 \mathrm{ppm}$ & $37.57 \pm 2.22$ & $36.16 \pm 2.21$ & $33.32 \pm 2.11$ & $32.95 \pm 2.05$ & $31.75 \pm 2.17$ & $29.91 \pm 1.95 *$ \\
\hline & Control & $38.37 \pm 2.68$ & $38.48 \pm 2.66$ & $38.55 \pm 2.63$ & $38.66 \pm 2.63$ & $38.78+2.61$ & $38.92 \pm 2.59$ \\
\hline
\end{tabular}

Values having $*, * *$ and $* * *$ are significantly differ from three respective pre-feeding values at $\mathrm{P} / \mathrm{0} 0.05,0.01$ and 0.001 respectively.

Assiut Vet.Med.J. Vol. 18, No. 35, 1987. 


\section{HAEMATOLOGICAL PARAMETERS AFTER DIETARY AFLATOXIN}

Table (2)

Haematological changes in Rabbits given dietary aflatoxin in different doses (0.1, 0.2 and 0.4 ppm)

\begin{tabular}{|c|c|c|c|c|c|c|c|}
\hline \multicolumn{2}{|c|}{$\begin{array}{l}\text { Diatary doses of } \\
\text { aflatoxin ppm \& } \\
\text { haematological items }\end{array}$} & \multirow{2}{*}{$\begin{array}{c}\begin{array}{c}\text { before feeding } \\
\text { dietary } \\
\text { aflatoxin }\end{array} \\
42.05+0.22\end{array}$} & \multirow{2}{*}{$\frac{\begin{array}{c}\frac{2 \mathrm{nd}}{\text { after }} \\
\text { feeding }\end{array}}{41.78+0.25}$} & \multirow{2}{*}{$\frac{\begin{array}{c}\frac{5 \text { th day }}{\text { after }} \\
\text { feeding }\end{array}}{41.65+0.28}$} & \multirow{2}{*}{$\frac{\begin{array}{c}\text { 10th day } \\
\text { after } \\
\text { feeding }\end{array}}{41.41 \pm 0.24}$} & \multirow{2}{*}{$\begin{array}{c}\begin{array}{c}15 \text { th day } \\
\text { after } \\
\text { feeding }\end{array} \\
41.12+0.26^{*}\end{array}$} & \multirow{2}{*}{$\begin{array}{l}20 \text { th day } \\
\text { after feeding } \\
\text { aflatoxin }\end{array}$} \\
\hline & $0.1 \mathrm{ppm}$ & & & & & & \\
\hline (PCV) & $0.2 \mathrm{ppm}$ & $41.57 \pm 0.30$ & $41.27 \pm 0.32$ & $39.45+0.50 *$ & $38.72+0.82 * *$ & $38.21 \pm 0.75 * * *$ & $37.70 \pm 0.66 * * *$ \\
\hline$\%$ & $0.4 \mathrm{ppm}$ & $39.76 \pm 0.49$ & $38.32+0.49$ & $36.25+0.64^{* * *}$ & $35.38 \pm 0.63^{* * *}$ & $33.97 \pm 0.58 * * *$ & $33.64+0.43 * * *$ \\
\hline & Control & $41.14+0.51$ & $41.01 \pm 0.51$ & $41.00+0.48$ & $40.98+0.47$ & $40.87 \pm 0.49$ & $40.80+0.80$ \\
\hline \multirow{4}{*}{$\begin{array}{c}(\mathrm{Hb}) \\
9 \%\end{array}$} & $0.1 \mathrm{ppm}$ & $13.27 \pm 0.09$ & $13.22+0.08$ & $13.14+0.11$ & $13.12 \pm 0.11$ & $13.03+0.10$ & $12.87 \pm 0.13 *$ \\
\hline & $0.2 \mathrm{ppm}$ & $13.22 \pm 0.06$ & $12.97 \pm 0.06 *$ & $12.29 \pm 0.13 *$ & $12.11 \pm 0.12^{* * *}$ & $11.74+0.20^{* * *}$ & $11.19 \pm 0.25 * * *$ \\
\hline & $0.4 \mathrm{ppm}$ & $13.26+0.06$ & $12.66 \pm 0.07 * * *$ & $11.90+0.17^{* * *}$ & $11.55 \pm 0.14 * * *$ & $11.29+0.19 * * *$ & $10.81 \pm 0.12 * * *$ \\
\hline & Control & $13.22+0.09$ & $13.18+0.10$ & $13.19+0.10$ & $13.20 \pm 0.11$ & $13.17+0.11$ & $13.16 \pm 0.11$ \\
\hline \multirow{4}{*}{$\begin{array}{l}\text { (RBCs) } \\
\times 10^{6} / \mathrm{mm}^{3}\end{array}$} & $0.1 \mathrm{ppm}$ & $5.53 \pm 0.03$ & $5.49 \pm 0.04$ & $5.42 \pm 0.05$ & $5.35+0.06^{*}$ & $5.30+0.05 * *$ & $5.20 \pm 0.06^{* * *}$ \\
\hline & $0.2 \mathrm{ppm}$ & $4.91 \pm 0.23$ & $4.75 \pm 0.23$ & $4.40 \pm 0.24$ & $4.19 \pm 0.19 *$ & $4.04 \pm 0.23 *$ & $3.92 \pm 0.22 * *$ \\
\hline & 0.4 ppm & $4.91 \pm 0.23$ & $4.45 \pm 0.32$ & $4.25 \pm 0.24$ & $3.98 \pm 0.22 * *$ & $3.80 \pm 0.17 * *$ & $3.52 \pm 0.13 * * *$ \\
\hline & Control & $5.10 \pm 0.25$ & $5.08+0.25$ & $5.08+0.25$ & $5.08 \pm 0.25$ & $5.07 \pm 0.25$ & $5.06 \pm 0.25$ \\
\hline \multirow{4}{*}{$\begin{array}{c}(\mathrm{MCHC}) \\
\%\end{array}$} & 0.1 ppm & $31.56+0.23$ & $31.66 \pm 0.24$ & $31.56 \pm 0.33$ & $31.68+0.34$ & $31.43+0.31$ & $31.45+0.29$ \\
\hline & $0.2 \mathrm{ppm}$ & $31.80 \pm 0.14$ & $31.42 \pm 0.13$ & $31.15+0.38$ & $31.32 \pm 0.44$ & $31.07+0.34$ & $29.72 \pm 0.48 * * *$ \\
\hline & $0.4 \mathrm{ppm}$ & $33.42+0.58$ & $33.06 \pm 0.35$ & $32.85 \pm 0.41$ & $32.69 \pm 0.52$ & $33.27 \pm 0.58$ & $32.15+0.36$ \\
\hline & Control & $32.10+0.37$ & $32.10+0.38$ & $32.17 \pm 0.37$ & $32.18+0.36$ & $32.20+0.37$ & $32.24+0.37$ \\
\hline \multirow{4}{*}{$(M C V) u^{3}$} & $0.1 \mathrm{ppm}$ & $75.99+0.69$ & $75.94+0.28$ & $76.75 \pm 0.42$ & $77.38 \pm 1.05$ & $77.91+0.92$ & $78.78+1.11$ \\
\hline & $0.2 \mathrm{ppm}$ & $85.63+3.53$ & $87.98+3.87$ & $90.85+4.01$ & $93.05 \pm 2.63$ & $95.86+4.10$ & $97.50 \pm 2.41$ \\
\hline & $0.4 \mathrm{ppm}$ & $81.66 \pm 3.96$ & $88.69+5.62$ & $86.78+4.31$ & $90.08+4.34$ & $90.16+3.48$ & $95.97 \pm 2.51 * *$ \\
\hline & Control & $82.22+4.65$ & $82.21+4.65$ & $82.18+4.66$ & $82.14+4.67$ & $82.14+4.67$ & $82.14+4.67$ \\
\hline \multirow{4}{*}{$\begin{array}{l}\text { (MCH) } \\
\text { uug }\end{array}$} & $0.1 \mathrm{ppm}$ & $23.98+0.19$ & $24.04+0.18$ & $24.23 \pm 0.30$ & $24.51+0.31$ & $24.56+0.30$ & $24.77 \pm 0.30 *$ \\
\hline & $0.2 \mathrm{ppm}$ & $27.25 \pm 1.11$ & $27.66 \pm 1.19$ & $28.31 \pm 1.20$ & $29.12 \pm 1.00$ & $29.47 \pm 1.22$ & $29.00 \pm 1.28$ \\
\hline & $0.4 \mathrm{ppm}$ & $26.99 \pm 1.15$ & $29.43+2.12$ & $28.53+1.50$ & $29.48+1.43$ & $29.92+0.93$ & $31.25+0.98$ \\
\hline & Control & $26.47 \pm 1.75$ & $26.49 \pm 1.74$ & $26.52 \pm 1.75$ & $26.54 \pm 1.75$ & $26.54 \pm 1.76$ & $26.56 \pm 1.76$ \\
\hline \multirow{4}{*}{$\begin{array}{c}\text { (WBCs) } \\
\times 10^{3} / \mathrm{mm}^{3}\end{array}$} & $0.1 \mathrm{ppm}$ & $7.97 \pm 0.49$ & $8.37 \pm 0.45$ & $8.65 \pm 0.45$ & $8.88 \pm 0.45$ & $8.94+0.46$ & $9.18 \pm 0.51$ \\
\hline & $0.2 \mathrm{ppm}$ & $7.90 \pm 0.48$ & $8.61 \pm 0.45$ & $8.85 \pm 0.46$ & $7.51 \pm 0.44$ & $7.51 \pm 0.43$ & $7.21 \pm 0.34$ \\
\hline & $0.4 \mathrm{ppm}$ & $7.86 \pm 0.48$ & $8.72+0.45$ & $8.41 \pm 0.45$ & $8.24+0.43$ & $8.06 \pm 0.43$ & $7.08 \pm 0.37$ \\
\hline & Control & $7.82 \pm 0.60$ & $7.79 \pm 0.60$ & $7.76+0.59$ & $7.74 \pm 0.59$ & $7.71+0.58$ & $7.66+0.57$ \\
\hline \multirow{4}{*}{$\begin{array}{l}\text { Platlegs } \\
\times 10^{\prime} / 1\end{array}$} & $0.1 \mathrm{ppm}$ & $72.40+3.41$ & $71.80 \pm 3.46$ & $69.04 \pm 3.10$ & $67.90+3.10$ & $65.91 \pm 2.94$ & $62.70 \pm 2.46 * *$ \\
\hline & $0.2 \mathrm{ppm}$ & $70.17 \pm 3.10$ & $69.34+2.99$ & $64.00+2.54$ & $60.60 \pm 2.57^{*}$ & $56.17 \pm 2.37 * *$ & $54.50 \pm 2.04^{* * *}$ \\
\hline & $0.4 \mathrm{ppm}$ & $68.18 \pm 3.17$ & $62.75+2.95$ & $56.88+2.85$ & $51.80 \pm 2.04^{*}$ & $50.20+2.24^{*}$ & $48.85 \pm 1.89 * * *$ \\
\hline & Control & $72.20+4.24$ & $72.35+4.20$ & $72.84+4.07$ & $73.77 \pm 3.42$ & $74.91 \pm 3.42$ & $76.48 \pm 2.90$ \\
\hline
\end{tabular}

Values having *, ** and *** are significantly differ from three respective pre-feeding values at $\mathrm{P} / 0.05,0.01$ and 0.001 respectively. 